\title{
XXV. Reply to that part of Mr. Weaver's paper relative to the mineral structure of the South of Ireland, which has appeared successively in the numbers of the Philosophical Magazine for April, May, and June, 1840
}

\section{Richard Griffith F.G.S.}

To cite this article: Richard Griffith F.G.S. (1840) XXV. Reply to that part of Mr. Weaver's paper relative to the mineral structure of the South of Ireland, which has appeared successively in the numbers of the Philosophical Magazine for April, May, and June, 1840, Philosophical Magazine Series 3, 17:109, 161-179, DOI: 10.1080/14786444008650143

To link to this article: http://dx.doi.org/10.1080/14786444008650143

册 Published online: 01 Jun 2009.

Submit your article to this journal ¿

ЦIl Article views: 4

$Q^{\mathbf{2}}$

View related articles $₫$ 
LONDON AND EDINBURGH

\title{
PHILOSOPHICAL MAGAZINE
}

\author{
A N D \\ JOURNAL OF SCIENCE. \\ [THIRD SERIES.] \\ $S E P T E M B E R$ 184.0.
}

XXV. Reply to that part of Mr. Weaver's Paper relative to the Mineral Structure of the South of Ireland, which has appeared successively in the Numbers of the Philosophical Magazine for April, May, and June, 1840. By RICHARD Griffith, F.G.S. London and Dublin*.

[With a Plate.]

$\mathbf{H}$ AVING rend with much care Mr. Weaver's paper published in successive Numbers of the Philosophical Magazine, relative to the mineral structure of the south of Ireland, \&c., in which he endeavours to support his own views $t$ in opposition to mine, respecting the order of succession of the rocks, and the geological position to which each is referable, I think it incumbent on me briefly to reply to those views and statements, which are quite inconsistent with facts carefully observed by me, and represented in my large geological map, as well as in several sections, exhibiting what appears to me to be the true order of succession of the strata of the south of Ireland: some of these sections have been published in the Journal of the Geological Society of Dublint, and others in the Numbers of this Magazine for March last.

As the boundaries of the several rock districts as represented on the map, and their relative positions as exhibited in the sections, differ materially from those published by Mr. Weaver, they are considered by him to be imaginative compositions, and consequently unworthy of credit; but I hope to be able to prove that my map and sections are founded solely on a careful observation of facts, and in no case from hypothetical deductions.

- Communicated by the Author.

$\uparrow$ See vol.v. Transactions of the Geological Society of London, second series. I See vol. ii. part 1 .

Phil. Mag. S. 3. Vol. 17. No. 109. Sept. 1840. M 
CEOLOCICAL STRUCTURE OF THE SOUTH OF IRELAND.

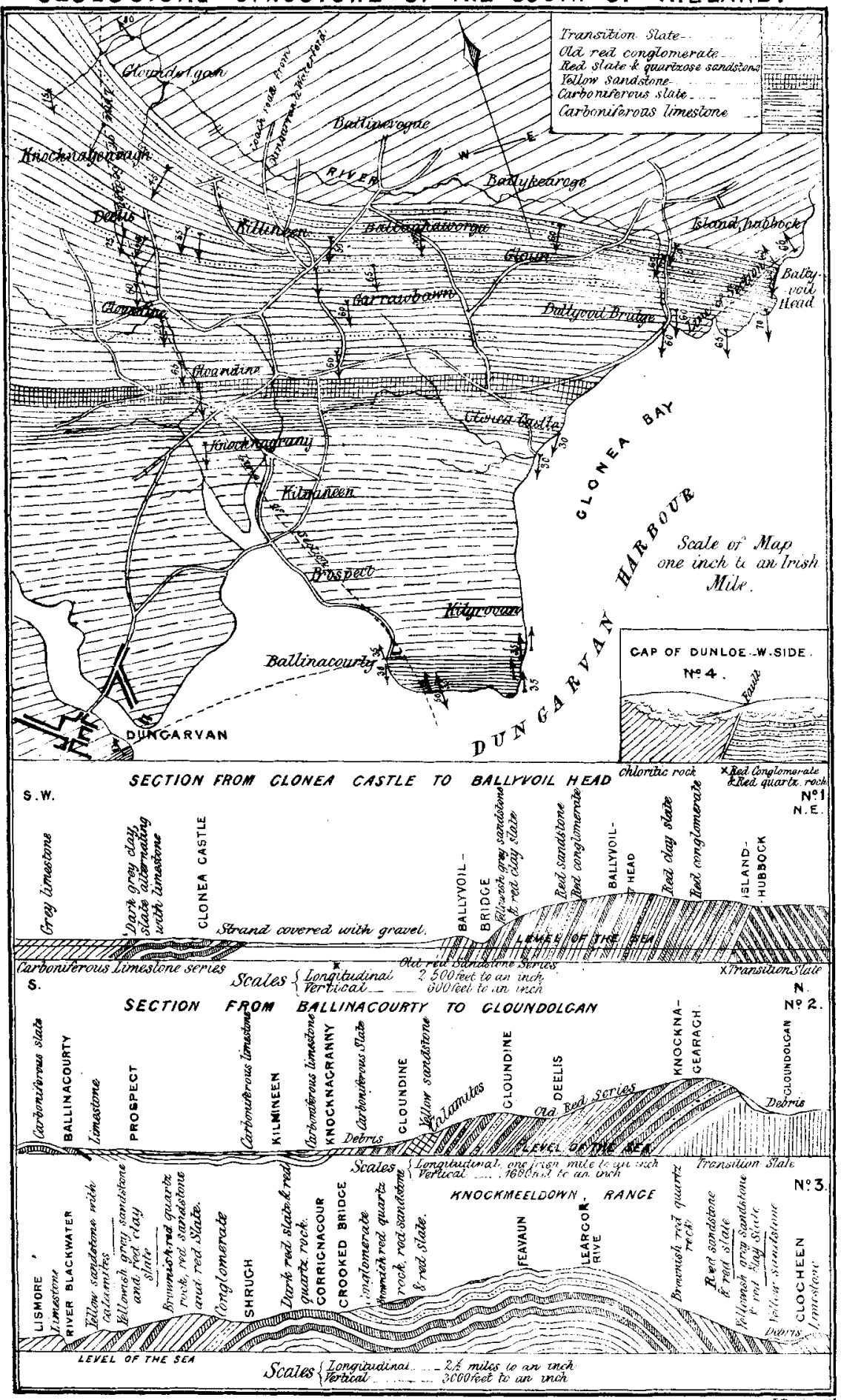


It is quite true that in the counties of Waterford, Cork and Kerry, I have made considerable changes in the colouring of my large geological map of Ireland, as compared with the small one appended to the Second Report of the Irish Railway Commissioners; but I should observe that, at the period of the publication of that map, and of the condensed Outline of the Geology of Ireland which accompanied it, I entertained doubts as to the accuracy of my views regarding the true position in geological sequence of some of the arenaceous and schistose strata of our southern districts. From the Wernerian character of my geological education, I found it almost impossible to conceive that quartz-rock and clayslate could be newer than the old red sandstone, or even belong to that series; and consequently when $I$ found that the coarse conglomerates of the counties of Tipperary and Waterford, which rest unconformably on undoubted transition slate, alternated with, and were succeeded in an ascending order by red clayslate and red and gray quartz-rock, I was induced to refer the whole series to the transition class; but, judging from their unconformable position in regard to the older clayslate, I considered them to belong to a newer transition series, and described and coloured them as such.

Soon after the publication of the Railway Report I made a careful re-examination of our southern counties, and on comparing the well-characterized old red sandstones of the Slieve-naman and Galties mountains of the county of Tipperary, and of the Cahirconree or Slieve Meesh range of the county of Kerry, with the conglomerate series of the county of Waterford, I found them to be identical in geological position, and to present no difference in mineral character beyond a superior fineness in the grain of the upper members of the red slate series which occur in the valleys of the rivers Blackwater and Lee in the counties of Waterford and Cork. Under these circumstances it became evident that I should either obliterate the old red sandstone from my map, and class the whole with the transition series; or assuming the unconformable pnsition of the red conglomerate and slate with regard to the older clayslates as an indication of a distinct period of formation, arrange them with that series of rock to which the name of old red sandstone has been given by British geologists.

In colouring the large geological map of Ireland, I adopted the latter principle, and thereby removed the anomaly which occurred in the small one, in which the conglomerate series of the mountains of Clare, Tipperary, and the north of Kerry were coloured as old red sandstone, while rocks occupying 
the same geological position, and presenting the same mineral character and composition (as in the Monavoullagh and Knockmildown mountains, and other portions of the counties of Waterford, Cork and Kerry) were coloured as belonging to the upper portion of the transition series. The investigation which led to this change having been very extensive and minute, enabled me to make numerous corrections in the detail of the outlines of the rock districts throughout the southern counties, and I think it right firmly to assert that every one of those subdivisions to which Mr. Weaver has applied the term gratuitous, has been the result of careful observations laid down on the spot, on a map on a large scale. Whether the subdivisions of the strata I have made may or may not eventually be considered as indicative of the boundary of distinct formations, still they will be valuable as indicating the boundaries of different rocks presenting distinct mineral characters and fossil remains. Thus, in my map and sections I have endeavoured to represent with accuracy the relative positions of the several rocks as they occur in geological sequence, and when a more correct nomenclature shall be established, it can be applied to both without difficulty and without altering a single line.

Mr. Greenough, in his introductory memoir to the new edition of his geological map of England, has classed the old red sandstone with the graywacke formation, and has quoted from Dr. M'Culloch's System of Geology, the characters of the formation as exhibited in Scotland, which he thinks are equally just when applied to the west of England, and in my opinion correspond very accurately with those of Ireland, particularly of the south; but I still adhere to the propriety of separating these strata from the transition class on account of their almost universal unconformability*, which forms a stronger line of distinction between the transition slate and the old red series than we find between the old red and the strata which succeed it, where no unconformability is observed, each suite, in the ascending series, succeeding the other in regular succession without any break, as far up at least as the new red sandstone; consequently, there is really more difficulty in determining the line between the old red sandstone and the carboniferous limestone series, than between it and the transition slate ${ }^{\circ}$.

* The only examples of conformability that I am acquainted with, occur in the west of the counties of Cork and Kerry. See paper by me in the Lond. and Ed. Phil. Mag. for March last, pp. 161-175

$\dagger$ The lower beds of the carboniferous limestone in many parts of Ireland, alternate with yellowish gray sandstone, which graduate into old red. 


\section{Mr. R. Griffith on Mr. Weaver's Paper relative}

As to the term old red sandstone, I agree with most others in thinking it objectionable ; but if this rock occurs in similar positions and presents similar mineral characters in the west of England, in Scotland, and in Ireland, a local name, as " Devonian," cannot be considered suitable, and the provincial term killas, recommended by $\mathrm{Mr}$. Greenough, though preferable, as not indicating any particular locality, does not appear to be applicable to a general series of rocks.

But I am forgetting the object of this communication, and must return to Mr. Weaver. In common with all geologists connected with Ireland, I feel much indebted to him for his laborious investigations in that country; and although I differ from him in many most material hinging points, still I fully admit that he has effected much that is accurate and valuable. Entertaining such feelings towards him, I regret to find that he has not entered upon the discussion of the differences between our respective geological labours with the fairness I should have expected, as, in making his strictures on my geological maps and papers, he has compared the explanation which accompanied the production of my large geological map, with the small one and the "Geological Outline" appended to the Railway Report. As my large geological map was exhibited at the meeting of the British Association at Newcastle in 1838, at the time I read my paper on the geological structure of the south of Ireland, and as in that paper I mentioned the change that I had made in relation to the old red sandstone series of the southern counties, Mr. Weaver in considering that paper should have referred to the map which it was meant to illustrate, and not to the small geological map, the discrepancies in the colouring of which, as already expressed, it was intended to correct. Similar observations are applicable to the papers, also referred to by Mr. Weaver, read before the Geological Societies of London and Dublin, in May and June, 1839, both of which, as mentioned in the commencement of those papers, were communicated on the presentation of a copy of my large geological map, published in March of the same year.

Instead of comparing these several papers, all of which refer to the geological structure of the south of Ireland, with the large geological map, Mr. Weaver has compared them with the small map, and the "Geological Outline" which accompanied it; we need not therefore be surprised at his observing differences and incongruities, and through them attempting to throw discredit on everything which I have done.

It is true that $\mathrm{Mr}$. Weaver has introduced notes in several 
places referring to the large geological map, in the first of which he states, "that his paper was drawn up before he had seen another geological map on a large scale, published in 1839 ;" and he observes, "that as the alterations that have been made in the new map do not materially interfere with the course of his argument, which in the first instance bears on the map attached to the outline, he has left the text unaltered." Now in his text Mr. Weaver does not confine his observations to the outline and small geological map, but refers equally to the three papers read by me before the British Association, and the Geological Societies of London and Dublin, the whole being compared with the small geological map, though at the period of the publication of his paper in April 1840, my large geological map had been in the possession of the London Geological Society for eleven months, and was to be seen exhibited in Mr. Gardner's, in Regent Street, for upwards of a year ; so that it does appear extraordinary, that $\mathrm{Mr}$. Weaver, who in the commencement of his paper alludes to my several communications above-mentioned, in each of which my large geological map is mentioned, should not have seen it when he drew up his paper for the Philosophical Magazine.

With this explanation I will conclude my observations on the subject of the discrepancies noticed by Mr. Weaver between my small geological map, and the sections and papers intended to illustrate the large one.

In comparing $\mathrm{Mr}$. Weaver's geological map of the south of Ireland with mine (the large one), it must be admitted that the differences are very considerable, both in the great scale and in the detail. The latter is not to be wondered at, as I possessed much better maps, and had many opportunities of examination in almost every locality; but in regard to the great features, some explanation appears to be necessary. $\mathrm{Mr}$. Weaver considers the whole of the schistose strata situated to the south of the river Suire in the county of Waterford, and thence to the south coast of the county of Cork, to belong to the transition series, on the northern part of which, particularly on the summits of the Knockmildown and Monavoullagh mountains, strata belonging to the old red sandstone series are superimposed in an unconformable position; and that the limestone of the valleys of the rivers Suire and Blackwater belong to the carboniferous series, while that of the valleys of the rivers Bride, Lee, \&c. is transition, and alternates with the transition slate.

According to my view, the transition slate within the abovementioned limits is confined to the dark gray slate district 


\section{6}

Mr. R. Griffith onMr. Weaver's Paper relative

south of the conglomerate of the valley of the Suire and east of that of the Monavoullagh mountains; while the conglomerate of these mountains rests unconformably on the slate strata to the north and east, and dipping to the southward, forms the substratum or base of the whole of the arenaceous, quartzose and schistose strata to the southward; and consequently, as these conglomerate beds are admitted by Mr. Weaver to belong to the old red sandstone series, the strata which rest upon them cannot belong to the transition class. I am also decidedly of opinion that the limestones of the valleys of the Suire, the Blackwater, the Bride, and the Lee, all occur in the same geological position, being placed on the top of the series, and that as the limestone of the valleys of the Suire and Blackwater are admitted by Mr. Weaver to be carboniferous, all the others must likewise belong to the same series.

In proof of the accuracy of these views, I formed with great care a section passing through this district nearly in a north and south direction; and if this section exhibits a correct representation of the relative positions of the several rocks, Mr. Weaver's views must be erroneous.

This section was exhibited at Newcastle in 1838 ; at the Geological Society of London, in May, 1839, in illustration of my paper; and subsequently at the Geological Society of Dublin, in June, 1839, and has since been published in the Journal of that Society.

I shall now proceed to consider Mr. Weaver's objections to my sections, both as to the principle of their construction and their accuracy.

$\mathrm{He}$ objects to the principle of making the scale of the height much greater than the scale of length, as he observes that " without considerable labour it leads to inaccuracy, as such sections, unless done correctly, instead of conveying precise information, tend rather to mislead the judgement." I quite agree to the position that an inaccurate section will tend to mislead; but if a section be made with care, and the relative positions of the rocks be accurately laid down according to the respective scales, no error can arise, though the angle of the dips will be necessarily increased.

The direct advantage to be derived from making the scale of height greater than the scale of length is, that supposing the scale of 8 to 1 be taken, the length of the paper on which the work is laid down is but $\frac{1}{8}$ th of the length which it would be, if equal scales of length and height were adopted; and in long sections this is most important, by bringing the whole subject under the eye at one time, instead, as must otherwise be the case, of having it in a long roll, or different portions 
placed one beneath the other, by which means the continuity is broken.

Suppose the scale of height adopted for a section of a mountainous district be 2000 feet to an inch, and the distance between the termini be 100 miles, on equal scales, the length of such a section would be 22 feet; while by adopting a scale of 8 to 1 for the height, the length would be but 2 feet 9 in., and if carefully constructed the latter would give as clear a representation of the structure of the country as the other.

In regard to the second point, namely, the accuracy of my sections, Mr. Weaver observes, "that they appear to him in many respects drawn rather according to the conceptions of their author, than the occurrences in nature." This is certainly not complimentary; but as my sections through the same district differ in many important points from those made by Mr. Weaver, I cannot be surprised at the opinion: my consolation is, that should I prove mine to be correct, his opinion of my work will be applicable to his own.

The part of my section near the east coast to which Mr. Weaver objects, is from the valley of the river Suire to the south coast in the county of Cork; and first, as he observes, respecting "that part which lies between the valley of the Suire and the vale of Dungarvan, which latter extends westward to the Blackwater."

As far southward as the conglomerate of the Monavoullagh mountains, which rests unconformably on the old clayslate of the county of Waterford, there is no difference of opinion between Mr. Weaver and me; we both consider the limestone trough of the Suire to be carboniferous limestone, and the red slate and conglomerate to be the old red sandstone; but Mr. Weaver states that I am incorrect in making the old clayslate to the south of the Suire dip north; he says, the dip is to the south. Now I have examined the stratification with great care, both previously and subsequently to the publication of his paper, and I must state, that in the line of my section from the hill of Carrick southward by Millvale to Rathcormuck, the general dip of the cleavage in the old slate series is to the south, but the dip of the strata, as determined by the sedimentary lines, is to the northward; consequently Mr. Weaver in this case must have mistaken cleavage for siratification. It should be observed in this place, that although the slate strata dip towards the north, they are not conformable with the overlying conglomerate of the valley of the Suire, the latter dipping to the north at an angle of $80^{\circ}$, while the ends of the slate beds, where the junction is clearly visible, abut obliquely against the conglomerate, and dip $30^{\circ}$ to the west of north at angles varying from $35^{\circ}$ to $60^{\circ}$. 
We may next consider the Monavoullagh conglomerate, which in his map $\mathrm{Mr}$. Weaver shows as an insulated tract, surrounded by transition slate; I, on the contrary, show in my section a precipitous escarpment to the north, but a gradual declivity towards the south and south-west. If Mr. Weaver be correct, his conglomerate, which he represents as a mountain cap, must rest unconformably on the transition slate on the south as well as on the north side; now, I positively assert that such is not the fact, but that the alternating series of red clayslate and conglomerate, which presents so striking an escarpment on the north face of the mountain range, forms the lower part of the red slate series, and that proceeding from the summit of Crotty's rock to the southward we regularly ascend in the series, till at length in approaching the Blackwater near Lismore, we meet the yellow sandstone with calamites, which in so many localities alternates with the carboniferous limestone, that I have been induced to consider it rather as the lowest member of the carboniferous limestone than the upper part of the old red sandstone series*. Now if I am right in this position, what becomes of Mr. Weaver's mountain cap, or of the occurrence of the old transition slate to the southward of the Monavoullagh mountains? As an additional proof of the correctness of my views on the subject, I have made a careful examination of the district roithin the last month, and have prepared a plan which has been constructed with great care, and which, I think, will set the matter at rest.

The plan represents that portion of the county of Waterford extending from Ballyvoil Head in a western direction, along the valley of the Ballyvoil river to Gloundolgan, a distance of four miles, and southward from thence to Dungarvan. In this district we have the unconformable outgoing of the conglomerate of the Monavoullagh mountains, extending in an eastern direction without interruption to the coast at Ballyvoil Head. Now Mr. Weaver states $\dagger$ in his paper, "that there is no apparent connexion whatever between the horizontal sandstone and conglomerate of the Monavoullagh range and those beds of conglomerate and red slate of the coast which continue eastward from Dungarvan in several separate discontinuous bands interstratified with the other transition rocks." In opposition to this opinion, I beg to state, that the alternating strata of red clayslate and conglomerate of the Monavoullagh escarpment, does extend uninterruptedly from Crotty's rock to the shore at Ballyvoil Head, where they rest equally in an unconformable position on the transition slate.

- See Lond. and Ed. Phil. Mag. for March, 1840, p. 173.

† See Lond. and Ed. Phil. Mag. for April, 1840, p. 279. 
The contact of the conglomerate with the transition slate is clearly visible at Island Hubbock, about a quarter of a mile north of Ballyvoil Head, and their unconformability is unquestionable, as the conglomerate rests upon the upturned ends of the slate, and strongly adheres to them. In illustration of this fact, I beg to refer to the section No. 1, which gives an accurate representation of the red slate and conglomerate strata as they occur, resting unconformably on the dark gray transition slate, from Island Hubbock westwards. The succession is as follows :

1. Unconformable base composed of alternations of blackish gray and reddish-gray clayslate with chlorite slate and gray quartz-rock, the blackish-gray clayslate greatly predominating; dip of strata from $10^{\circ}$ to $20^{\circ}$ east of north, at angles varying from $60^{\circ}$ to $75^{\circ}$.

2. Alternations of reddish-gray and red conglomerate, reddish-gray compact sandstone, and dark-red slate, the conglomerate predominating; dip of strata about $35^{\circ}$ west of south, at angles varying from $60^{\circ}$ to $80^{\circ}$. The thickness of these alternating strata is about 300 feet.

3. Dark reddish-gray clayslate, reddish-gray quartz-rock, and sandstone, the slate predominating: thickness about $\mathbf{3 0 0}$ feet.

4. Dark red micaceous sandstone, and red clayslate, with occasional beds of conglomerate, the sandstone predominating; dip $25^{\circ}$ west of south at angles varying from $60^{\circ}$ to $85^{\circ}$ : thickness about 750 feet.

5. Dark-red slate, red quartz-rock and sandstone, the slate predominating: thickness about 300 feet.

6. Brownish-red quartzose rock, red clayslate, and yellowish-gray sandstone, the sandstones predominating: dip $20^{\circ}$ west of south, on an average at an angle of $65^{\circ}$ : thickness about 600 feet.

To the south of the yellowish-gray sandstone and red slate the strata are concealed from view by diluvial matter for a distance of about half a mile, beyond which alternations of dark-gray carboniferous slate and limestone are visible, both of which contain abundance of fossils belonging to the carboniferous limestone series.

I also give a section of the strata as they occur, from the unconformable contact of the red slate and conglomerate with the transition slate at Gloundolgan, to the coast at Ballynacourty in the harbour of Dungarvan, in which the succession of the strata between the lower conglomeritic base, the yellow sandstone, the carboniferous slate, and superincumbent carboniferous limestone are clearly shown.

Now if we compare these sections with that originally 
published by me as extending southward from Crotty's rock in the Monavoullagh mountains to Lismore, we find exactly the same suite interposed between the conglomerate base and the carboniferous limestone of the valley of the river Blackwater.

It is true, that the distance between Crotty's rock and Lismore, is greater than between Gloundolgan and Knocknagranny, in section No. 2, or between Ballyvoil Head and Ballyvoil bridge, in section No. 1; but it will be observed by referring to the plan, that the conglomerate and red slate at the coast dip to the south at an angle of $70^{\circ}$; while at Gloundolgan, four miles west of Ballyvoil Head, they dip south at an angle of $45^{\circ}$; further to the westward the dip is south at an angle of $15^{\circ}$; and as we approach the summit of the Monavoullagh mountains at Crotty's rock, the strata effect a nearly horizontal position. Owing to this circumstance, though the section is complete at Ballyvoil Head in the horizontal distance of one mile and a half, yet between Crotty's rock and Lismore the same suite occupies a horizontal distance of eighteen miles.

Having stated these facts, I think it unnecessary to do more than observe that Mr. Weaver's argument in proof of the impossibility of the red slate and conglomerate at Crotty's rock composing a part of the same series with the red slate and conglomerate of Ballyvoil Head, namely, the nearly horizontal position of the one, and the highly inclined angle of the strata of the other, is untenable; and I confess I am surprised at such an argument being used, as every practical geologist must be aware of its weakness.

The northern part of Mr. Weaver's section between the Suire and the Blackwater does not take the same line as mine, as his crosses over the Knockmildown mountains, and mine over the Monavoullagh range situated to the east; but to enable me to test the accuracy of his section, I have made one nearly in the same line. (See section, No.3, in the plate.) If we compare this section with Mr. Weaver's, nothing can be more dissimilar. Mr. Weaver's section represents a base of graywacke slate, which supports unconformably a cap of old red sandstone; but according to my section, it is evident that

e entire mountain range belongs to the old red sandstone series. The anticlinal axis is exposed to view in the valley of the river Ownashad, at Corrignagour, three miles north of Lismore : it consists of alternations of dark-red slate and darkred quartzose rock, the slate predominating. These strata are succeeded both on the north and south sides of the axis by beds of brownish-red quartz-rock, red sandstone, and red clayslate, occasionally associated with fine-grained conglomerate, $a$ thin bed of which appears at the surface on the south 
side of the axis at Shrugh, and on the north side at Crooked Bridge on the road from Lismore to Clogheen. In the lower part of this series the quartz-rock and sandstone predominate, but in the upper part the red clayslate is the prevailing rock.

Descending the hill on the north side towards Clogheen, and on the south towards Lismore, we find the last-mentioned rocks succeeded by alternations of gray sandstone and red clayslate, beyond which we have the limestone series alternating in the commencement with dark-gray clayslate. There is much diluvial matter at the base of the declivity on the north side, and in consequence the yellow sandstone with calamites is not visible there; although to the north of Lismore, at Reaf, and in other parts of both valleys, it may be observed associated with the dark-gray slate, which alternates with the lower beds of the carboniferous limestone.

If we compare the succession of rocks which form the stratification of the Knockmildown mountains, as above described, with those that occur at Ballyvoil Head and Gloundolgan, it would appear that the lowest visible rocks of the Knockmildown range belong to the upper part of the old red sandstone suite, which will account for the absence of the thick beds of conglomerate which abound in the lower part of the series in the Monavoullagh range, as at Crotty's rock, Gloundolgan and Ballyvoil Head.

In my paper printed in the Journal of the Geological Society of Dublin*, I have entered so fully into my reasons for considering that the limestones of the valleys of the Suire, the Blackwater, the Bride, the Lee, \&c., occupy the same geological position, both by the order of succession of the strata and by fossils, that I do not think it necessary to discuss the subject a second time; and conceiving that $I$ have shown that the red slates and conglomerates which overlie the conglomeritic base at Crotty's rock, at Gloundolgan, and at Ballyvoil Head, occupy the entire space between the dark-gray transition slate and the carboniferous limestone, I think I have substantiated my case, and shown that the strata situated to the south of the unconformable junction with the transition slate of the county of Waterford, do belong to a newer series, to which, for reasons already given, I have applied the name of old red sandstone in my large geological map, and in the papers referable to it. I shall, however, reply to one statement of Mr. Weaver's in regard to the stratification of the ridge interposed between the valley of the river Blackwater and the Bride, which, he observest, " are said by Mr. Griffith to partake of a similar composition to that of the northern

* See vol. ii. part 1.

† See Lond. and Ed. Phil. Mag. for April, 1840, p. 228. 
side of the Blackwater near Lismore, \&c., forming in the centre of the ridge an anticlinal axis." He further observes, "The anticlinal axis I have not seen, the dip which I observed being throughout to the south," \&c.

Now I must assert that the anticlinal axis does exist, and is clearly visible in the section of the strata of this ridge, which is exposed to view on the west bank of the river Blackwater, which in this locality takes a southern course, and cuts through the ridge between Killahally, opposite to Dromana Castle on the north, and Camphire on the south, as may be clearly seen by reference to my large geological map. The anticlinal axis is visible nearly in the centre between Camphire and Killahally, the strata at the axis and on either side consisting of alternations of red quartzose rock and red clayslate, which are succeeded both on the north and south by alternations of gray quartz-rock and red slate, those to the north dipping north at angles varying from $60^{\circ}$ to $85^{\circ}$, and those to the south dipping at angles varying from $35^{\circ}$ to $40^{\circ}$. These strata are succeeded on the south side by yellow sandstone containing calamites, and lastly, by alternations of limestone and black clayslate. On the north side the yellow sandstone is not visible, owing to a covering of diluvial matter, but the limestone alternating with black clayslate is visible immediately to the north of Killahally, dipping to the north at an angle of $60^{\circ}$; consequently, there can be no doubt of the identity of the limestone of the valley of the river Blackwater at Lismore, and thence to Dungarvan, with that of the Bride at Tallow, Camphire, \&c.

It is to be observed, that the limestone of the valley of the Blackwater immediately to the south of Lismore, as represented in my section, published in the Journal of the Geological Society of Dublin, dips to the south at a very high angle; but fortunately this is not universally the case, as at Killahally, three miles south-east of Lismore, the strata, as above-stated, dip to the north, which in regard to the trough-shape of the limestone, proves by observation what I had previously supposed to be the case by induction.

In like manner I am prepared to follow my section in detail from the valley of the Bride to the south coast at Cork Head, and to show that at each point the strata do actually dip in the direction exhibited on the section; but I must remark in reference to the section published in the Journal of the Geological Society of Dublin, that in one point, namely, on the west side of Cork harbour, the lithographer has represented the beds of the carboniferous limestone as abutting against the subjacent carboniferous slate, while in the original drawing, as in nature, they are conformable. 
I shall now make a few remarks with regard to $\mathrm{Mr}$. Weaver's section as compared with my own, and particularly with reference to the position of the limestone of the several troughs in which it occurs.

We agree with respect to the limestone of the valleys of the Suire and the Blackwater, both considering it to be carboniferous; but what are the geological circumstances under which these limestones occur? They both rest conformably on the red slate and conglomerate series, which in the valley of the Suire $\mathrm{Mr}$. Weaver calls old red sandstone, but in the valley of the Blackwater transition slate. In respect to the latter, I have shown that he is mistaken by means of my original section, and the sections from Ballyvoil Head and Gloundolgan; but Mr. Weaver in his section exhibits the carboniferous limestone of the Blackwater at Lismore in the form of a trough, the north side dipping to the south, and the south side to the north, which is not the fact; as in that locality, as already mentioned, the carboniferous strata dip to the south on both sides of the valley, on the north side at an angle of $30^{\circ}$, and on the south at an angle of about $60^{\circ}$.

If $\mathrm{Mr}$. Weaver had carefully examined the dips of the strata, he must have observed this fact; and, following the principle he has adopted in other places, he should have included this limestone in his transition suite; but knowing this was not the fact, from its connexion with the great limestone field of Ireland, he has represented this rock at Lismore as a trough having reverse dips on the opposite sides of the valley.

We next come to the limestone of the valley of the Bride at Tallow, which Mr. Weaver in his section truly represents as a trough having dips in opposite directions; but this limestone, though undoubtedly the same in geological position, in lithological character, and in fossils, as the limestone of the Blackwater, he makes transition, though from its position and true trough shape, he must have considered it to rest on the top of the red slate series which lie beneath it on the north side of the valley dipping to the south, and on the south side to the north.

I shall now make a few observations respecting the extensive district represented by me as carboniferous slate, which occupies the greater portion of the south of the county of Cork, and which Mr. Weaver has included in his transition district. In geological position it rests upon the red slate and conglomerate series; near its commencement it is usually interstratified with gray or yellowish-gray sandstone and arenaceous slate, which frequently contain calamites, and in some cases, as at the Old Head of Kinsale, where the strata are 
unusually compact, the sandstone passes into quartz-rock, but it still exhibits the calamites.

In many localities the carboniferous slate includes beds of limestone, which, logether with the slate, contains fossils similar to those which occur in the lower beds of the carboniferous limestone. This is the case at Blackball Head*, on the north-western extremity of Bantry bay; also at Brickeen island, near Killarney; at Kenmaret; at Clonea Castle on the coast of the county of Waterford, south-west of Ballyvoil Head; at Goat island in Ardmore bay on the same coast; at Kilnamack, near Knocklofty bridge; on the south side of the valley of the Suire above Clonmel, and many other localities.

The following are a few of the fossils which occur in the beds of carboniferous slate which are interstratified with the limestone at the following different localities :

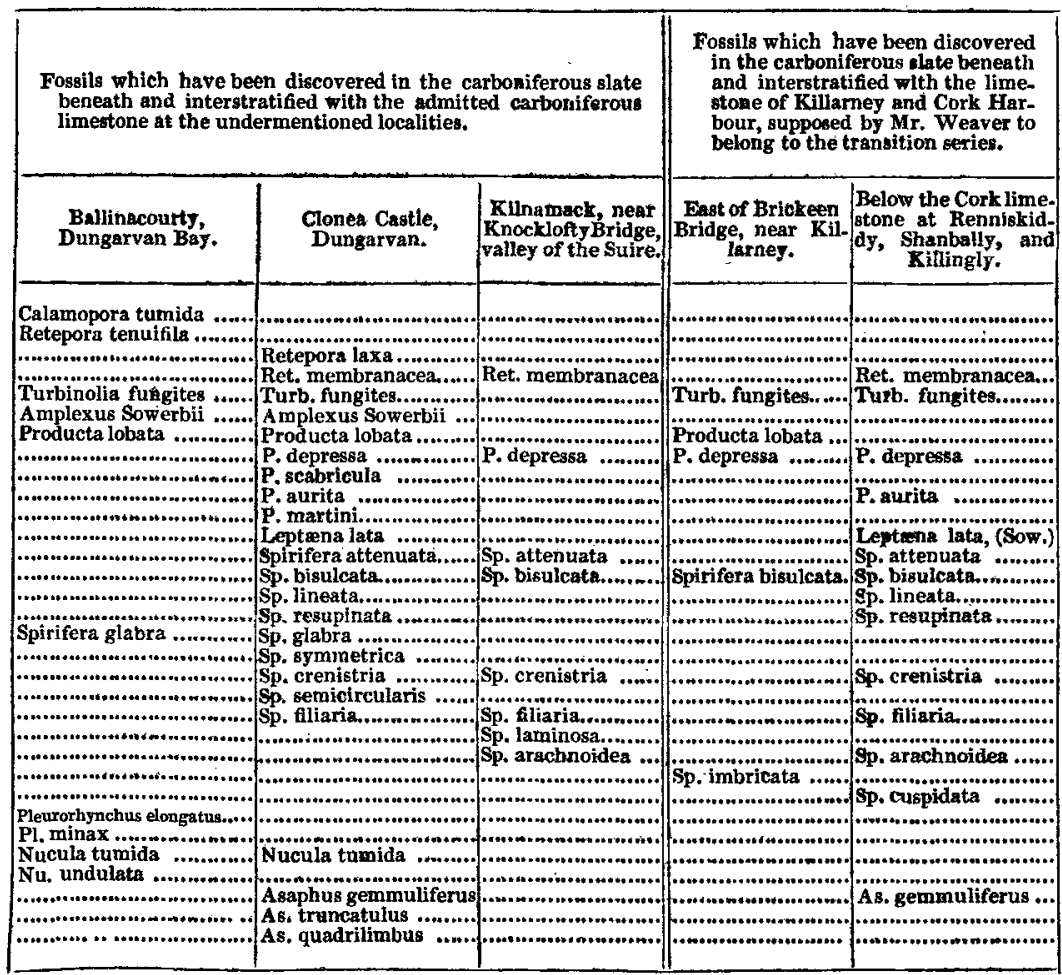

- In the dark-gray clayslate of Blackball Head I found Spirifer semicircularis, Phillips.

$\uparrow$ Retepora membranacea occurs in the carboniferous slate at Roughty bridge above Kenmare, where it rests conformably on yellow sandstone containing calamites. 
I shall next advert to $\mathrm{Mr}$. Weaver's observations respecting my section which extends from Brandon bay, at the extremity of the peninsula of Dingle in the county of Kerry, in an eastern direction across the Cahirconree or Slieve Meesh range of mountains, thence traversing the limestone valley of Castle island, and terminating in the great millstone grit of Munster*.

Of this section, Mr. Weaver observes, "That the portion which more immediately claims attention, is that which extends from the summit of the old red sandstone of the Slieve Meesh range, to the carboniferons limestone of Castle island. The former is represented as constituting nearly a cap or sheet, formed on an inclined plane, from west to east, the strata corresponding and succeeding each other in that direction to the junction with the carboniferous limestone." Mr. Weaver further observes, that he " knows of no such arrangement; on the contrary, the strata of the old red sandstone are accumulated to a great depth, and certainly, in some quarters, at least to the level of the sea, being disposed in a gently arched form from north to south."

In the latter observation $\mathrm{Mr}$. Weaver is perfectly correct : in fact, the Slieve Meesh or Cahirconree range may be compared to a semicone, having its base to the west and apex to the east; the western base presents a precipitous escarpment, the lower region of which is occupied by highly-inclined strata, consisting of dark gray clayslate, which on the outer edges alternates with purple clayslate; the nearly upright ends of these strata are covered by a series of unconformable beds of compact red sandstone and red conglomerate, alternating with coarse red slate; near the summit, these strata present a nearly horizontal arrangement, in a north and south direction, but they dip to the eastward at a moderate ungle. On approaching the declivities of the cone, both to the north and south, the conglomerate strata dip rapidly, on the one side, towards Tralee bay, and on the other, towards the bay of Castlemaine. From the summit, the eastern dip is continued towards the apex of the cone at Currens; but the lower bed, which rests on the ends of the transition slate, does not continue to form the surface, but dipping more rapidly to the eastward than the ridge of the hill, it is succeeded by a number of beds of conglomerates and coarse slate, each cropping out to the westward. At the eastern extremity of the range, or the apex of the cone, the upper portion of the red slate and conglomerate series is succeeded in a conformable position by beds of fine-grained yellowish-gray sandstore

\footnotetext{
* See Journal of the Geological Society of Dublin, vol, ii,, part 1.
} 
of the carboniferous series, some of which contain calamites and many obscure casts of bivalves, one of which was named by Mr. Sowerby as the Avicula modiolaris*. The upper beds of the sandstone alternate with a dark-gray, and occasionally blueish-gray quartzose-rock, and they are succeeded by dark-gray clayslate, alternating with carboniferous limestone. These strata, at Riversville quarry, which I have lately visited, dip to the east at an angle of $15^{\circ}$. It was here that $\mathrm{Mr}$. Weaver could discover traces only of the graywacke formation; now the upper part of the quarry just mentioned contains thin beds of carboniferous limestone; and immediately to the south and east we have large quarries of that rock partaking of the same strike and dip as the schistose beds beneath it, which rest conformably on the strata belonging to the old red sandstone series of the Slieve Meesh range. How Mr. Weaver can consider beds in such a situation to belong to the transition series, I cannot understand; for, as to his idea of there being a protrusion $\dagger$ of graywacke from benoath the old red sandstone, it cannot be sustained, there being no reverse dip; on the contrary, the yellow sandstone and dark-gray slate rest conformably on the old red slate, and are succeeded by strata of limestone having the same strike and dip $\ddagger$.

In regard to fossils in the yellow sandstone and carboniferous slate of this locality, as I mentioned in my paper which has been quoted by Mr. Weaver, they contain numerous imperfect casts of Producta, Spirifera, Terebratula, Crinoidea, and Retepora; but though I lately sought, with much care, I did not discover any varieties of Orthis or Favosites, supposed by $\mathrm{Mr}$. Weaver to occur there.

The foregoing description of the structure of the Cahirconree, or Slieve Meesh range, is similar to that contained in my paper just alluded to, which has been verified by recent observations; but as Mr. Weaver was not convinced of the inaccuracy of his views respecting the carboniferous slate at the eastern base of the Slieve Meesh range, which, notwithstanding my section and description, he still considered to belong to the graywacke series, I do not expect that what I now repeat will have the effect of changing his opinion. But it should be observed, that this carboniferous slate, which un-

- Journal of the Geological Society of Dublin, vol. ii., part 1.

† See Lond. and Ed. Phil. Mag. for April, p. 291.

† In my section already alluded to, the lithographer did not make an accurate copy of the original, and has made the limestone strata to rest unconformably upon the carboniferous slate, while in nature these strata are conformable. 
derlies and alternates with the undoubted carboniferous limestone of the valley of Castle island, is precisely similar to the carboniferous slate which underlies and is interstratified with the lower beds of the carboniferous limestone at Clonea Castle, on the east coast of Waterford, near Dungarvan; it is likewise similar to the rock which alternates with the limestone of Cork harbour, of Killarney, of Kenmare, and of many other localities in the south of Ireland; consequently, as Mr. Weaver persists in the opinion that the limestone of Cork harbour, of Killarney, of Kenmare, \&c., belongs to the transition series, it would be fatal to his argument to class the carboniferous slate of Clonea Castle, or of Currens, with the carboniferous limestone series. But I will observe, that in the localities just mentioned, beds of undoubted carboniferous limestone alternate with slate, precisely similar in fossils, as well as in lithological character, to that of Cork harbour, \&c.

I do not think it necessary to pursue this argument further than to observe, that in endeavouring to form a distinction between the admitted carboniferous limestone of the valley of the river Laune, and that of Killarney, and also between the admitted carboniferous limestone of the valley of the Blackwater, below Mallow, and that westward of Clonmeen Castle in the same valley, Mr. Weaver has involved himself in an untenable dilemma. There is no difference in geological position, in mineral character, or in fossils, between the limestone of Killarney, and that of the valley of the Laune between Beaufort bridge and Killorglin, which are all contained in the same valley, and all repose on the same base; and a similar statement may be made in regard to the limestone of the valley of the river Blackwater, above Clonmeen Cast!e, and that at and below Mallow; yet Mr. Weaver considers the limestone of Killarney and that above Clonmeen Castle to be transition, and that below Beaufort bridge and Mallow to be carboniferous.

After what has been said, I hardly think it necessary to reply to the observations contained in the postscript to Mr. Weaver's paper*, in which he endeavours to show that I am incorrect in considering the conglomerate and red sandstone of the Gap of Dunloe, and that to the south of the Lower Lake of Killarney generally, as identical with the red sandstone, the conglomerate, and red slate of the Cahirconree or Slieve Meesh range.

* Published in the Philosophical Magazine for June last. [L. and E. Phil. Mag, vol. xvi. p. 471.]

Phil. Mag. S. 3. Vol. 17. No. 109. Sept. $1840 . \quad$ N 


\section{On the Mineral Structure of the South of Ireland.}

It should be observed, that the red conglomerates and red slates of the district of Killarney are situated on the south side of the carboniferous limestone valley of Castlemaine, while those of Cahirconree are on the north side; that the upper beds of both graduate into the carboniferous limestone series, at Currens on the north side, and at Brickeen island in the Lower Lake of Killarney on the south side of the valley. The unconformability of the conglomerate beds with the transition series on Cahircouree, and their conformability on McGillacuddy's Reeks, the Purple Mountain, \&c., is no proof that the rocks are not identical, as, in England, the old red sandstone graduates both into the Silurian and mountain limestone series.

In respect to the fault described by me, the occurrence of which is doubted by Mr. Weaver, I shall observe, that it is clearly visible at the Gap of Dunloe and at Brickeen island; and I will assert, that the positions of the old red sandstone strata on one side, and the chloritic rocks on the other, in both those places, are as clearly indicative of a fault as any I have ever seen. On the west side of the Gap of Dunloe, we have a perpendicular cliff upwards of 200 feet in height, which is traversed by a nearly upright cut or crack about 20 feet in breadth. On the south side of this cut we find strata of dark-green chloritic quartz-rock dipping to the south at an angle of $30^{\circ}$, while the strata on the north side dip to the west at an angle of $10^{\circ}$, and are composed of rather finegrained conglomerate and a red quartzose-rock or compact sandstone identical with that which lies beneath the red congiomerate of Cahirconree. I am of opinion that these appearances do prove that there has been a fault.

Figure No. 4 in the plate is an accurate representation of the fault as above described.

Similar observations are applicable to the appearances at Brickeen island. There also, the strata on the south side of the fault consist of green chloritic rock, having rather a slaty structure, which dip to the south; while on the north side, we have in succession, red quartzose-sandstone and red slate, red limestone, and yellowish-green slate containing calamites, abutting obliquely against the chloritic rock on the north side.

Towards the conclusion of his paper, Mr. Weaver observes, "Proceeding now to the Dingle peninsula, the succession given also by $\mathrm{Mr}$. Griffith from north to south, namely, from Brandon bay to Foylaturrive, is as follows: 1st, dark gray clayslate," \&c. "The above sentence is a misquotation from my paper. My words are, "If we make a section across the 
Dingle peninsula, from Foylaturrive on the south to Brandon bay on the north, we find that the strata consist of a base of dark blackish-gray clayslate," \&c. Now by reversing the points, Mr. Weaver has made the dark gray clayslate to occur on the north side of the peninsula, namely, at Brandon bay, while it really occurs on the south: the misquotation was doubtless unintentional, but as Mr. Weaver's argument was founded on this misconception, it is unnecessary to reply to it.

In concluding my observations, I cannot avoid expressing my regret that Mr. Weaver was not present either at the meeting of the British Association at Newcastle, or at the Geological Society of London, when I communicated my views relative to the geological structure of the south of Ireland; for, viva voce discussion tends more to clear up geological differences than lengthened written descriptions; and where both parties are in search of truth there is little difficulty in attaining it.

Dublin, July 8, 1840.

XXVI. Memoir on the Law of Substitutions, and the Theory
of Chemical Types. By M. Dumas.

[Continued from vol. xvi. p. 505, and concluded.]

\section{Organic Radicals.}

FOR some years organic chemistry has so frequently used what we call organic radicals, that it will appear singular to see, if not their existence, at least the reality of the absolute function which they have been made to play, here put in doubt.

We know that by the term organic radicals we mean to designate certain compound bodies which might fulfil their functions in the manner of simple bodies, and which might enter, as they do, and following the same laws, into combination with the various bodies of nature.

If by organic radicals, bodies analogous to cyanogen, to amidogen, to the oxalic or benzoic radical be intended, there is no doubt that there, in fact, compound bodies perform the function of simple bodies, like those analogous to them in mineral chemistry, the oxide of carbon, sulphuric acid, the binoxide of azote, and nitrous vapour.

But if by the term organic radicals we must, as M. Berzelius wishes, designate certain invariable compounds which would fulfil the function of the metals, the theory of types, while admitting their concurrence, cannot allow their permanency. 